\title{
Collaboration among Local Government Institutions in Achieving Public Information Openness
}

\author{
RozidatenoPutri Hanida ${ }^{1}$, Bimbi Irawan ${ }^{2}$, Syamsurizaldi ${ }^{3}$, Rahmatika Syaufi ${ }^{4}$ \\ ${ }^{1}$ RozidatenoPutriHanida; Andalas University, Padang, Indonesia ozidateno@ gmail.com \\ ${ }^{2}$ BimbiIrawan; BKPM Sumatera Barat Province, Padang, Indonesia \\ ${ }^{3}$ Syamsurizaldi; Andalas University, Padang, Indonesia \\ ${ }^{4}$ Rahmatika Syaufi; Andalas University, Padang, Indonesia
}

\begin{abstract}
Open Government is one of the main roads for accelerating development and ensuring sustainable development. One of the strategies to encourage open government is by implementing what is the mandate of the Law on public information openness well.For citizens, this law means a guarantee to citizens to obtain public information in order to increase their active role in governance. As for government institutions, the law provides the obligation to government institutions to open access to public information, actively (without preceded by the request), and passively (with the request by the requestor) to the community.However, when citizens try to access the public information, it is not uncommon for the answer to be obtained is "This is the system", "The procedure is like this", "I am not authorized".This is the background of research on how collaboration among local government institutions in Padang Panjang Municipality in realizing public information openness. With qualitative descriptive method, through the analysis of data in ethics and emic found that Local Government of Padang Panjang Municipality developed collaboration among government institutions that marked by the cooperation, interaction, compromise of some related elements to encourage public information openness.One of the ways implemented by Local Government of Padang Panjang Municipality is by the establishment of Management Officer of Information and Documentation or Pejabat Pengelola Informasi dan Dokumentasi (PPID) or consisting of Main PPID (PPID Utama) and Asssisytance PPID (PPID Pembantu).For the future, it is required a clear Standard Operating Procedure for the local government work unit to network each other in encouraging the openness of public information, so the impression that the responsibility of creating public information openness in Padang Panjang Municipality is only a function of PPID can be eliminated.
\end{abstract}

Key words: local government; government openness; information, collaboration. 


\section{Introduction}

Openness in governance has become something that must be done at every level of government. The current challenge is on user-oriented services that require sub-political decisions to be open (Musa, 2015). The form of openness in each government will be different, and that must be supported by a number of policies and the importance of participation (Gevelin 2009; Newman 2004). In Indonesia, the obligation to implement the openness of the government system was strengthened after the Indonesian Government launched the movement of Open Government Indonesia (OGI). One of the legal basis used in this open government movement is Law Number 14 of 2008 concerning Openness of Public Information. This policy regulates openess information and transparency in the state administration as a manifestation of the life of a democratic nation and state. In the era of democracy, everyone has the right to communicate and obtain information to develop their personal and social environment, as well as the right to seek, obtain, own, and store information by using all available channels (Nunuk Febrianingsih, 2012: 136). Law about Public Information Openness has guaranteed all citizens to be able to access all information from public bodies in accordance with the laws and regulations.

To implement the Law on Public Information Openness and its implementing regulations, an Information Commission is established which acts as an independent institution. The Information Commission has the function to establish technical guidelines for public information service standards and resolve public information disputes through mediation and / or nonlitigation adjudication (Article 1 paragraph 4). To determine the level of compliance of public bodies in implementing Law No. 14 of 2008 concerning Public Information Openness, these facts make Padang Panjang Municipality lag far behind its own neighboring region, Tanah Datar Regency, which ranks first in a number of assessment categories.

The Municipality of Padang Panjang is one of the local governments who is also working on improving public information. The Municipality Government of Padang Panjang seeks to collaborate among government institutions. This effort is carried out through interaction, compromise and cooperation with various interested parties in order to encourage public information openness in Padang Panjang Municipality. One of the actions taken by the Municipality Government of Padang Panjang is to form a Management Officer of Information and Documentation or Pejabat Pengelola Informasi dan Dokumentasi (PPID) consisting of the Main PPID and Assistant PPID. However, the efforts made by the Muicipality Government of Padang 
Panjang also cause other problems. The problem is the emergence of the impression that the responsibility to create public information openness in Padang Panjang Municipality is only in the hands of PPID. One of the causes of this problem arises because it is unclear the Standard Operating Procedure for local government institutions or Organisasi Perangkat Daerah (OPD) to network with each other in encouraging public information openness in Padang Panjang Municipality

Therefore, this paper tries to explain and analyze about how collaboration among local government agencies in Padang Panjang Municipality in realizing public information openness. The method used in this research is a qualitative descriptive research method, through ethical and emic data analysis. The data collection technique is done by direct observation in the field. Then conduct interviews with actors involved in the collaboration process among local government agencies in Padang Panjang Municipality and data from relevant documents to the research topic.

\section{PUBLIC INFORMATION OPENNESS OF PADANG PANJANG MUNICIPALITY}

Referring to the Information Commission Regulation Number 1 of 2010 concerning Public Information Service Standard, it is explained that each Public Agency is obliged to announce information that must be provided and announced periodically at least through official websites and announcement boards in a way that is easily accessible to the public (Article 20 Paragraph 1 and 2). To implement this regulation, the Municipality Government of Padang Panjang already has an official website, that is padangpanjang.go.id. On the initial appearance of the Padang Panjang Munilipatity's website, it looks quite complete by displaying information menu choices that can be accessed by the public, namely: Public Service Menu, Public Info, CCTV, Social Communication Media, Sub Domains, Licensing, PPID, Budget Transparency, Padang Panjang News, and Webmail. Ideally, the information flow in a government openness system is as follows; 
Figure 1. Flow of an ideal Information Openness System in Government

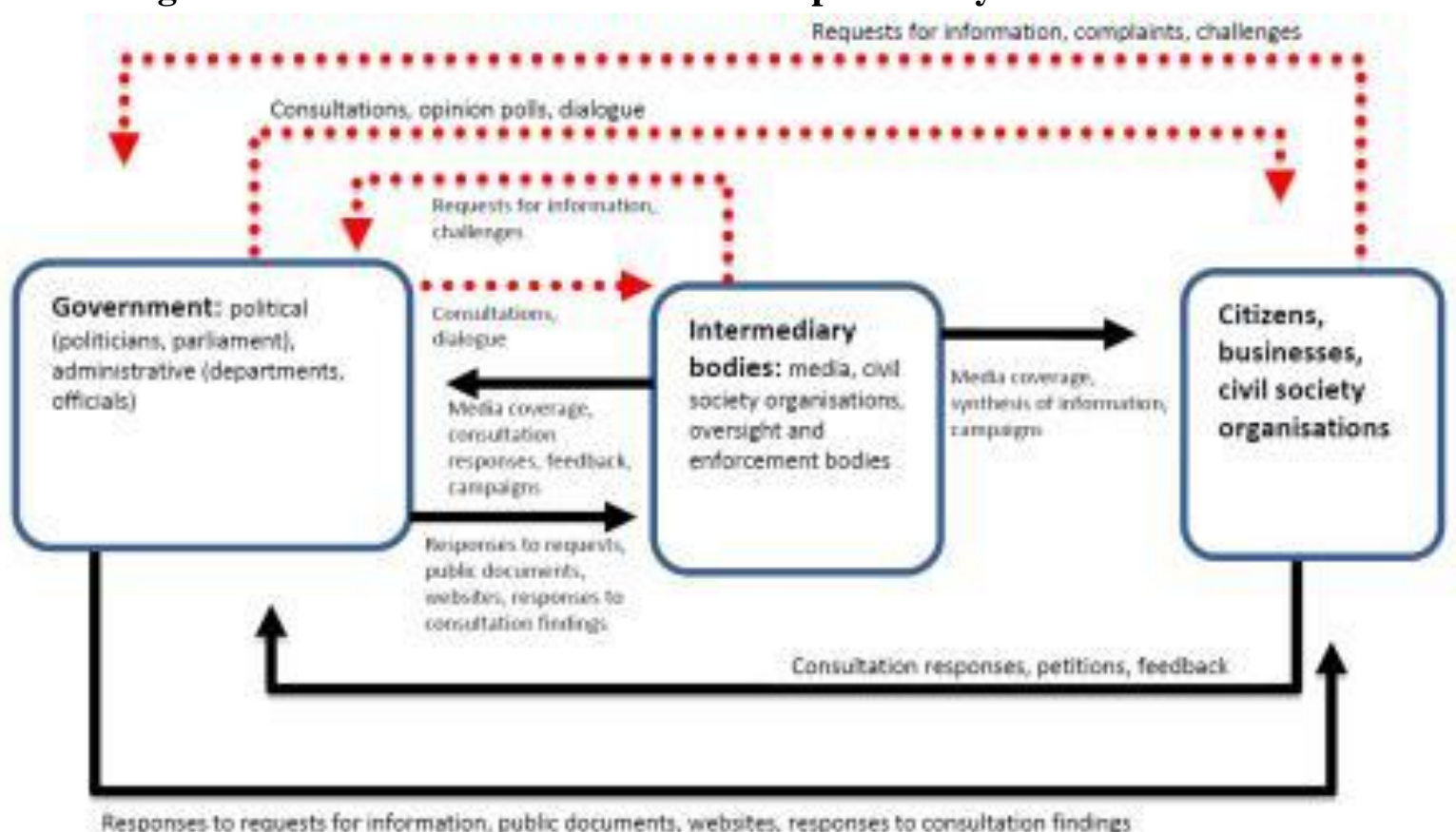

Source: Gavelin, 2009: 12

If further explored the Padang Panjang Municipality's website, it has not provided and announced information that is updated to the public. As has been well regulated in the Law Number 14 of 2008 concerning Public Information Openness, as well as in the Information Commission Regulation Number 1 of 2010 concerning Public Information Service Standard. This can be seen in the picture below:

Figure 2. Display of the Official Website of Municipality Government of Padang Panjang

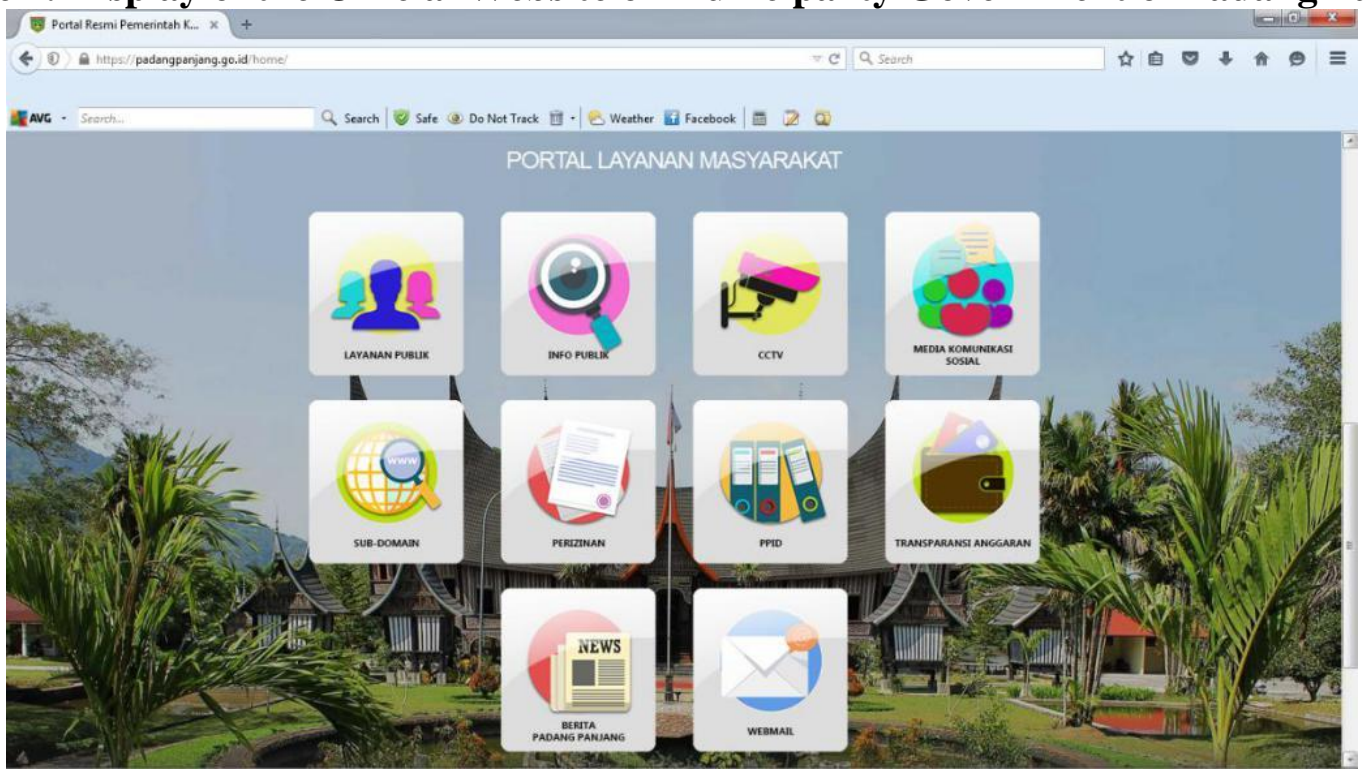

Source: padangpanjang.go.id, 
Public information openness should provide a variety of public information. In a census in the United States (Granickas; 2015) publishs priority data sets that must be displayed to the public, including; Asset openness, Budget, Business listings, Campaign finance contributions, Code Enforcement Violations, Lobbyist activity. If you look at the Padang Panjang PPID portal section, the published information that is still limited, only provides two menu options, namely Recapitulation of Public Information List and Public Information. In each of these menus only limited data is available. As a result the public cannot get complete data when accessing the PPID portal. This can be seen from the picture below:

Figure 3 Display of Padang Panjang PPID Portal for Recapitulation Menu of List of Public Information

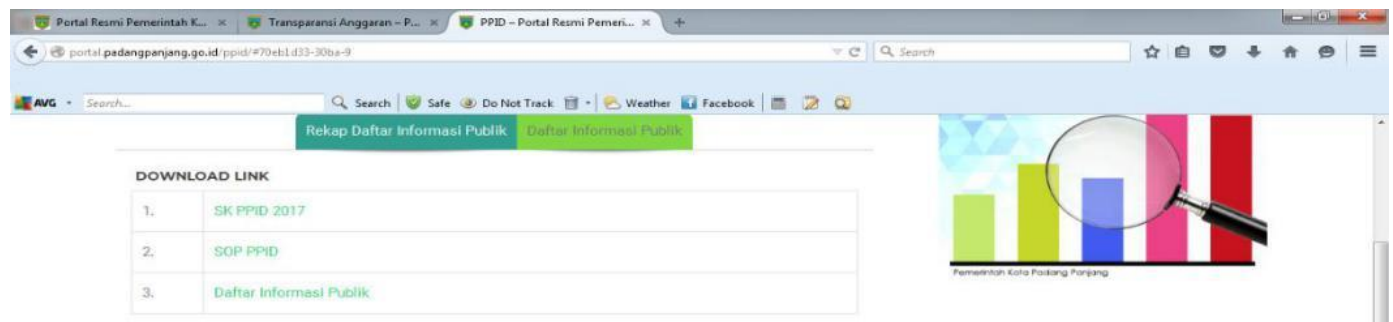

Source: padangpanjang.go.id, accessed on April 14, 2018

Based on the picture above, it can be seen that in the Recapitulation List of Public Information menu only provides information about the decree of PPID of Padang Panjang Municipalty 2017, standard operating procedure of PPID and List of Public Information that can be downloaded directly on the link provided. However, in the menu section the Public Information List consisting of link of Public Information Lists in several institutions in Padang Panjang Municipality cannot be accessed at all. This can be seen from the following picture: 
Figure 4. Display of Padang Panjang PPID Portal for Public Information List Menu

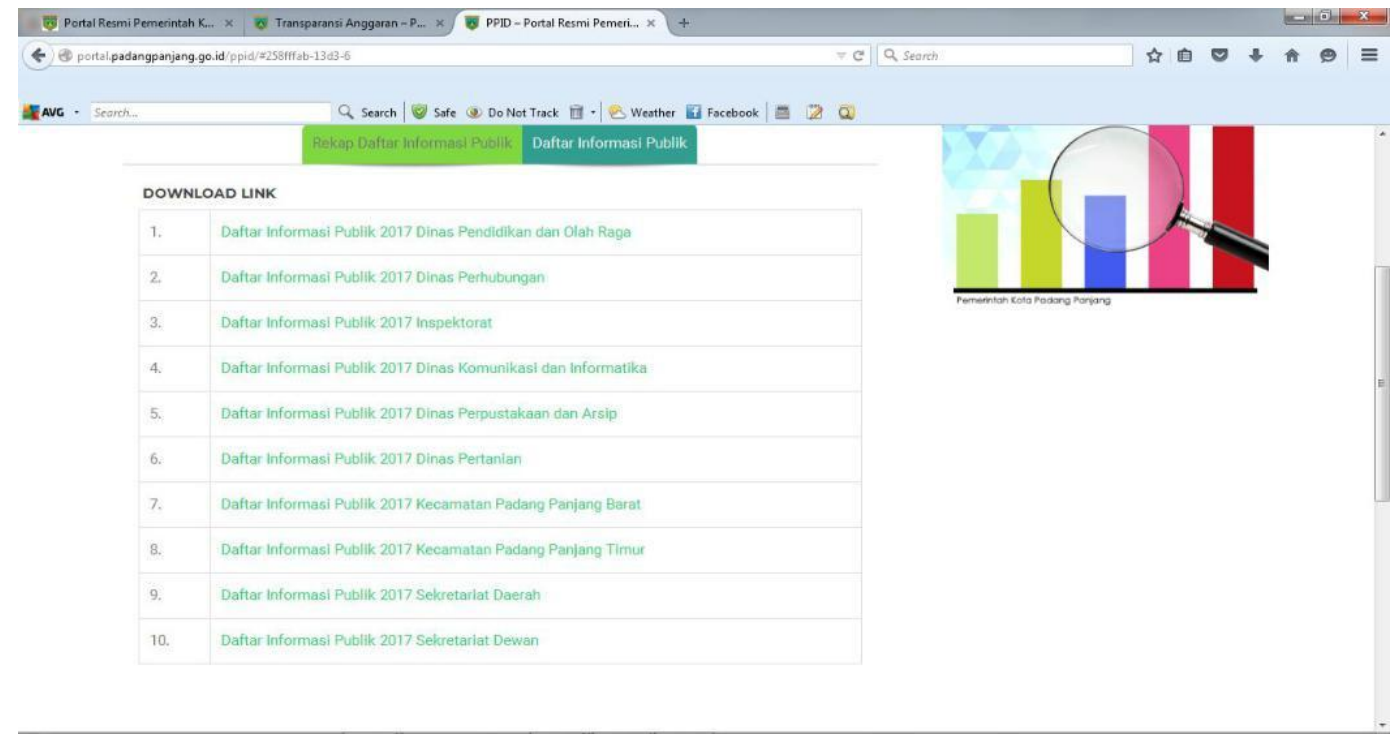

Source: padangpanjang.go.id,

The Municipality Government of Padang Panjang has issued the Padang Panjang Municiplity Regulation Number 10 of 2015 concerning Transparency and Public Participation. The stipulation of this local regulation is aimed at improving the management and information services within the Public Agency to produce quality information services and can be accountabled (Article 2). In the Padang Panjang Municipality Regulation on Transparency and Public Participation in article 6, it has been regulated that public agency have an obligation to provide information that includes:

1. List of all public information under its control, excluding excluded public information.

2. Results of the decision of the Public Agency and its considerations.

3. All existing policies and supporting documents.

4. Work plan of activities including the estimated annual expenditure of the Public Agency.

5. Public Agency Agreements with third parties.

6. Information and policies submitted by public officials in meetings that are open to the public.

7. Procedures for the work of employees of public bodies relating to public services,

8. Report on the service of access to public information as stipulated in local regulations and other legislation regulations. 


\section{IMPLEMENTATION ACTOR FOR OPENNESS OF PUBLIC INFORMATION IN THE REGION}

The implementation of services on information and documentation at the public agencies of the local government institutions in the local government environment is carried out by the Management Officer of Information and Documentation (PPID), The Municipality Government of Padang Panjang has established PPID in 2014. The establishment of PPID of Padang Panjang Municipality is determined by the Mayor of Padang Panjang Number: 489/479/WAKO-PP/2014 concerning the Formation of an Information Service Consideration Team, Management Officer of Information and Documentation, Assistant of Management Officer of Information and Documentation in the environment of Municipality Government of Padang Panjang. The Padang Panjang's PPID is attached to structural positions in charge of the function of public information of services and documentation. As an information service provider, PPID of Padang Panjang Municipality is responsible to the Mayor through the Regional Secretariat.

Then for the PPID office of Padang Panjang Municipality located in the Public Relations Division of Padang Panjang Municipality Secretariat, headed by the Head of Public Relations of Padang Panjang Municipality. To support the performance of PPID, the Municipality Government of Padang Panjang has formulated a Standard Operating Procedure (SOP) on public information services established through the Decree of Mayor of Padang Panjang Municipality Number 480/480/WAKO-PP/2014 concerning Standard Operating Procedure for Management of Information and Documentation in the Environment of Municipality Government of Padang Panjang. In section V points J in the Decree of Padang Panjang Mayor number 480/480/WAKOPP/2014, it is explained that in carrying out their duties the main PPID is assisted by the PPID assistants who are in the area of local government institutions based in their respective work units.

In 2017, the Municipality Government of Padang Panjang made changes in the PPID organization. This change was determined through the Decree of Padang Panjang Mayor Number: 487/43/WAKO-PP/2017 concerning the Formation of Information Service Consideration Team, Management Officer of Information and Documentation, and Assistant of Management Officer of Information and Documentation in the environment of Municipality Government of Padang Panjang. This change occurred to the Head of PPID previously held by the Head of Public Relations of Padang Panjang Municipality and at this time held by the Head of Agency of Communication and Informasi of Padang Panjang Municipality. This change occured because in 
early 2017 there were changes in several local government institutions in Padang Panjang Municipality. One of them is the transfer of the function of the Public Relations Division which was transferred to the Agency of Communication and Information. Previously, the Public Relations Division was only part of one of the fields in the Agency of Transportation, Communication, and Information. The following is the organizational structure of PPID of Padang Panjang:

Table 1. The Organizational Structure of PPID of Padang Panjang Municipality

\begin{tabular}{|c|c|c|}
\hline No. & Position in the Team & The Official \\
\hline 1 & Governing Board & Mayor of Padang Panjang \\
\hline 2 & Steering & Regional Secretary of Padang Panjang Municipality \\
\hline 3 & $\begin{array}{l}\text { Consideration Team of } \\
\text { Information Services }\end{array}$ & $\begin{array}{ll}\text { 1) Assistant of Government and People's Welfare at Regional } \\
\text { 2) } \\
\text { Assecretariat of Padang Panjang Municipality } \\
\text { Secretariat of Padang Panjang Municipality } \\
\text { 3) Assistant of Public Administration at Regional Secretariat } \\
\text { of Padang Panjang Municipality } \\
\text { 4) Expert Staff in the Field of Government, Law and Politics } \\
\text { 5) Expert Staff in the Field of Economy, Finance and } \\
\text { Development } \\
\text { 6) Expert Staff for Community and Human Resources } \\
\text { 7) Head of Legal and Human Rights Division at Regional } \\
\text { Secretariat of Padang Panjang Municipality }\end{array}$ \\
\hline 4 & PPID & $\begin{array}{l}\text { Head of Agency of Communication and Information of Padang } \\
\text { Panjang Municipality }\end{array}$ \\
\hline 5 & $\begin{array}{l}\text { c. Data Processing, } \\
\text { Documentation and } \\
\text { Archives } \\
\text { d. Complaints and } \\
\text { Information Dispute } \\
\text { Settlement }\end{array}$ & $\begin{array}{l}\text { Head of Information and Public Communication Division at } \\
\text { the Agency of Communication and Information of Padang } \\
\text { Panjang Municipality } \\
\text { Head of Information and Media Services Division at the } \\
\text { Agency of Communication and Information of Padang } \\
\text { Panjang Municipality } \\
\text { Head of Research and Development Division at Agency of } \\
\text { Communication and Information of Padang Panjang } \\
\text { Municipality } \\
\text { Head of Sub Division of Legal Assistance and Human Rights } \\
\text { at the Legal and Human Rights Division of Regional } \\
\text { Secretariat of Padang Panjang Municipality }\end{array}$ \\
\hline 6 & Assistant PPID & 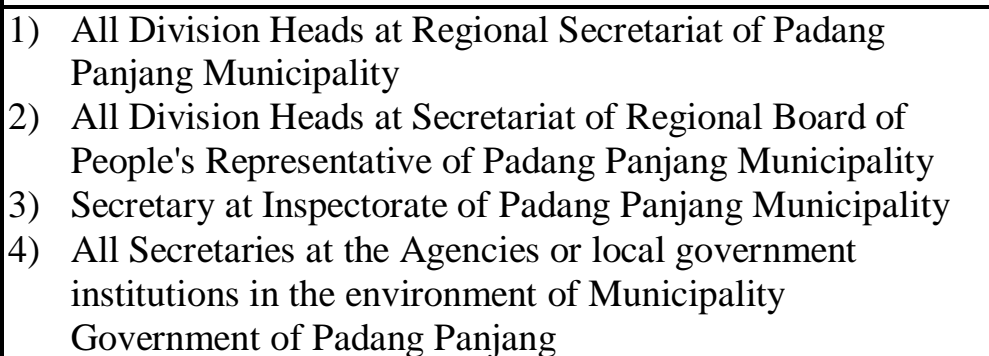 \\
\hline
\end{tabular}




\begin{tabular}{|c|c|c|}
\hline & & $\begin{array}{l}\text { 5) Secretary to the General Election Commission of Padang } \\
\text { Panjang Municipality } \\
\text { 6) Head of Administration Section at General Hospital of } \\
\text { Padang Panjang } \\
\text { 7) All Secretaries of the District Head in Padang Panjang } \\
\text { Municipality } \\
\text { 8) All Heads of Administration Section at Technical } \\
\text { Implementing Service Unit of the Government } \\
\text { Municipality of Padang Panjang }\end{array}$ \\
\hline 7 & $\begin{array}{l}\text { Information Officer: } \\
\text { a. Archivist Officer } \\
\text { b. Librarian } \\
\text { c. Public Relations Office } \\
\text { d. Computer Administration }\end{array}$ & $\begin{array}{l}\text { Ibnu Sectio Caesaria, S.IP, M.IKOM } \\
\text { Desmiati } \\
\text { Hartono, A. Md } \\
\text { Deny Saputra }\end{array}$ \\
\hline
\end{tabular}

Source: Decree of Padang Panjang Mayor Number: 487/43/WAKO-PP/2017 concerning the Formation of Information Service Consideration Team, Management Officer of Information and Documentation, and Assistant of Management Officer of Information and Documentation in the Environment of Municipality Government of Padang Panjang

PPID of Padang Panjang Municipality has the task to manage and provide information services and documentation in Padang Panjang Municipality. One of them is providing public information. The following is a list of categories of public information in Padang Panjang Municipality:

Table 2. Category of Public Information

\begin{tabular}{|c|c|c|}
\hline No & Information Category & Information Indicator \\
\hline 1 & $\begin{array}{l}\text { Open information } \\
\text { announced periodically) }\end{array}$ & $\begin{array}{l}\text { 1) Profile of Municipality Government of Padang } \\
\text { Panjang } \\
\text { 2) Report on the activities and performance of the } \\
\text { Municipality Government of Padang Panjang } \\
\text { 3) Financial statements } \\
\text { 4) Information regulated in the Act } \\
\text { 5) More detailed information based on requests for } \\
\text { information }\end{array}$ \\
\hline 2 & $\begin{array}{l}\text { Information that must be announced } \\
\text { immediately }\end{array}$ & $\begin{array}{l}\text { 1) Information on natural disasters } \\
\text { 2) Information on hazardous waste } \\
\text { 3) Information on land eviction } \\
\text { 4) Information that threatens the lives of many } \\
\text { people }\end{array}$ \\
\hline 3 & $\begin{array}{l}\text { Information that must be available at } \\
\text { all times }\end{array}$ & $\begin{array}{l}\text { 1) List of all public information under the control } \\
\text { of the Municipality Government of Padang } \\
\text { Panjang } \\
\text { 2) The decision of the Municipality Government of } \\
\text { Padang Panjang and the background of the } \\
\text { consideration } \\
\text { 3) All existing policies and supporting documents } \\
\text { 4) Work plan of programs and activities }\end{array}$ \\
\hline
\end{tabular}




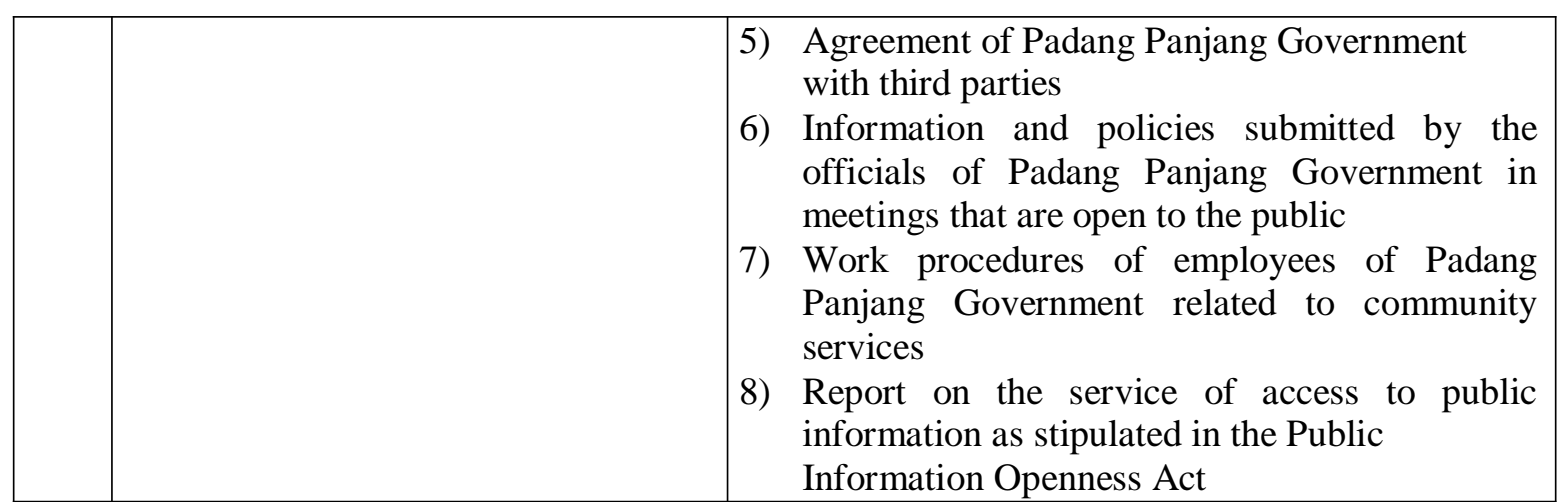

Source: Decree of Mayor of Padang Panjang Municipality Number 480/480/WAKO-PP/2014 concerning Standard Operating Procedure for Management of Information and Documentation in the Environment of Municipality Government of Padang Panjang

Based on the duties and functions carried out by PPID of Padang Panjang Municipality, PPID of Padang Panjang should be the leading sector to maximize the authority its possesses to realize information transparency in Padang Panjang Municipality.

\section{COLLABORATION AMONG LOCAL GOVERNMENT INSTITUTIONS IN PADANG PANJANG MUNICIPALITY IN THE IMPLEMENTATION OF OPENNESS OF PUBLIC INFORMATION}

As cited by Hanida (2017) about collaboration, that collaboration is defined as a cooperative, inter-organizational relationship that was negotiated in ongoing communicative process, although for Benton $(2013 ; 220)$ collaboration in the provision of public services involving two or more more levels of government (national, regional, state, and local) is not uncommon but collaboration must still be carried out, with various strategies (orla o'donnell 2012; Vigoda 2002). In this study the Municipality Government of Padang Panjang has formulated a Standard Operating Procedure (SOP) on public information services established through the Decree of Padang Panjang Mayor Number 480/480/WAKO-PP/2014 concerning Standard Operating Procedure for Management of Information and Documentation in the environment of Municipality Government of Padang Panjang. The establishment of the Standard Operating Procedure (SOP) is intended to make it easier for executing actors to carry out their duties and functions in the sense of collaborating.

Actors who must collaborate in local government organizations consist of Governing Board, Steering, information service consideration teams, main PPID fields, auxiliary PPIDs and information officers. Likewise, in Part V Points $\mathrm{J}$ in the Padang Panjang Mayor Decree Number 
480/480 / WAKO-PP / 2014, it is explained that in order to carry out the tasks, the main PPID is assisted by the assistants PPID that are in the environment of local government institutions based in their respective work units. At present, Main PPID of Padang Panjang Municipality consists of nine employees. These PPID employees play a role as leading sectors in implementing and creating information openness in Padang Panjang Municipality. In collaboration, the principle is a relationship of interdependence (Riley, 2002; 102) which requires sharing of power between institutions, each partner has the capacity to complement each other.

At present there is a problem in the system of implementation of information openness in Padang Panjang Municipality. The Main PPID of Padang Panjang Municipality does not have an annual report as stipulated in the Decree of Padang Panjang Mayor Number 480/480/WAKOPP/2014 concerning Operational Procedure Standard of Management of Information and Documentation in the Municipality Government of Padang Panjang. In the reporting section, there is a provision that the PPID has an obligation to report the report every year which includes: the amount of information received, the time needed to fulfill the information request, and the amount of the giving information and the refusal to give information. The emergence of this problem, one of which was caused by changes in several local government institutions in Padang Panjang Municipality in the beginning of 2017 ago. The transfer of functions of the Public Relations Division which was transferred to the Agency of Communication and Information had resulted in a change in the structure of the PPID. Previously, Head of PPID of Padang Panjang Municipality was held by Head of Public Relations Division. At this time, the Head of PPID is held by the Head of the Agency of Communication and Information.

To carry out its duties to create public information openness in the Padang Panjang Municipality, the Main PPID must have a complete list of Assistant PPID of Padang Panjang Municipality. This list is needed to make it easier for the Main PPID to coordinate with the Assistant PPID in the environment of local goverment institutions of Padang Panjang Municipality. In the mechanism of communication and work, the Assistant PPIDs will provide an annual report to the Main PPID. Then the Main PPID will make an annual report based on the recapitulation of the Assistant PPID annual report. As a result, the process of implementing information openness is difficult to monitor. It is undeniable that there is an Assistant PPID that does not provide an annual report to the Main PPID of Padang Panjang Municipality. So that the Main PPID cannot 
make annual reports in the form of performance achievements that have been made to create public information openness in Padang Panjang Municipality.

Commuity of Padang Panjang Municipality plays an important role in realizing public information openness in Padang Panjang Municipality. Community control is needed to encourage accountability and transparency in the administration of governance in Padang Panjang Municipality. It takes community participation to ask for their rights in obtaining information to public agency, because the policy of public information openness will be well implemented if there is an information applicant and there is a request for information. According to Ballit et al. in iqbal (2007) suggests that the provision of information may be said to be more demand (demand driven) than supply (supply driven). Therefore, the provision of information should be based on stakeholder needs. This is not only intended to increase stakeholder accessibility to information, but also to improve their socioeconomic status in their relevance to development activities. On the other hand, PPID of Padang Panjang Municipality has also never provided socialization to the public about the importance of the role of the community in realizing public information openness in Padang Panjang Municipality. Whereas with socialization, the community is expected to know that it has the right to obtain information and oversee the implementation of the government system.

It is very important for policy actors to map and invite stakeholder groups to collaborate in implementing a policy, including in implementing the policy of public information openness in Padang Panjang Municipality. In the implementation of development programs, stakeholders have an important role in the success of a development policy. The term of stakeholders are used to describe the community or organization that permanently receives the impact of the activity or policy, where they have an interest in the results of the activity or policy. This needs to be realized, given that the community does not always receive the impact fairly. Some communities may bear the costs and some other communities actually benefit from an activity or policy (Race and Millar 2006).

\section{CONCLUSION}

One of the legal basis used in the open government movement in Indonesia is Law Number 14 of 2008 concerning Openness of Public Information. This policy regulates information openness and transparency in the administration of the state as a manifestation of the life of a 
democratic nation and state. For citizens, this Act means providing guarantees to citizens to obtain Public Information in order to increase their active role in the administration of government. Whereas for government institutions the Act provides obligations to government institutions to open access to Public Information, actively (without precedence application) and passively (with the request by the Applicant) to the community.

Municipality Government of Padang Panjang seeks to collaborate among government agencies or institutions. This effort is carried out through interaction and cooperation with various interested parties in order to encourage public information openness in Padang Panjang Municipality. One of the actions taken by the Municipality Government of Padang Panjang is to form an Management Officer of Information and Documentation (PPID) consisting of the Main PPID and Assistant PPID. However, the efforts made by the Municipality Government of Padang Panjang also cause another problem. The problem is the appearance of the impression that the responsibility to create public information openness in Padang Panjang Municipality is only in the hands of PPID. One of the causes of this problem arises because it is unclear the Standard Operating Procedure for local government institutions to network with each other in encouraging public information openness in Padang Panjang Municipality.

The role of the community of Padang Panjang Municipality is also needed and plays an important role in realizing public information openness in Padang Panjang Municipality. Community control is needed to encourage accountability and transparency in governance. It's required community participation to ask for their rights in obtaining information to public agencies. The policy of public information openness will be implemented properly if there is an information applicant and there is a request for information request. Thus, it is very important for policy actors to map and invite stakeholder groups to collaborate in implementing a policy, including the implementation of a public information openness policy in the Padang Panjang Municipality.

\section{REFERENCES}

Benton, J. Edwin. 2013. Local Government Collaboration: Considerations, Issues, and Prospects. State and Local Government Review, 45(4) 220-223 
Febrianingsih, Nunuk. 2012. Keterbukaan Informasi Publik dalam Pemerintahan Terbuka Menuju Tata Pemerintahan Yang Baik. Jurnal : Rechts Vinding Online

Gavelin, Karin. At all. 2009 Open Government: beyond static measures. Involve

Granickas, Karolis. 2015. Open City: Local Government \& Open Data. European Public Sector Information Platform. ePSIplatformTopic Report No. 2015 / 07

Hanida, Rozidateno Putri. At all. 2017. Collaboration of Stakeholders In Formation and Development Nagari-Owned Enterprise Policy \& Governance Review Volume 1, Issue $3,(213-227)$

Iqbal, Muhammad, 2007. Analisis Peran Pemangku Kepentingan Dan Implementasinya Dalam Pembangunan Pertanian. Jurnal Litbang Pertanian, 26(3). Hal 89-99

Keputusan Walikota Padang Panjang Nomor 480/480/WAKO-PP/2014 Tentang Standar Operasional Prosedur Pengelolaan Informasi dan Dokumentasi di Lingkungan Pemerintah Kota Padang Panjang.

Musa, A., D. Bebic, P. Đurman. 2015. Transparency and Openness in Local Governance; A Case of Croatian Cities. HKJU - CCPA 15(2): 415-450

Newman, J., Barnes, M., Sullivan, H., \& Knops, A. 2004. Public Participation and Collaborative Governance. Journal of Social Policy, 33(02), 203-223.

O'Donnell, O. 2012 Strategic collaboration in local government A review of international examples of strategic collaboration in local government. Institute of Public Administration IPA Report No.2

Peraturan Daerah Kota Padang Panjang Nomor 10 Tahun 2015 Tentang Transparansi dan Partisipasi Publik.

Peraturan Komisi Informasi Nomor 1 Tahun 2010 tentang Standar Layanan Informasi Publik

Race, D. and J. Millar. 2006. Training Manual: Social and community dimensions of ACIARProjects. Australian Center for International Agricultural Research - Institute for Land, Water, and Society of Charles Sturt University, Australia.

Riley, John M. 2002 Stakeholders in rural development: critical collaboration in state-NGO partnerships Sage Publication

Undang-Undang Nomor 14 Tahun 2008 tentang Keterbukaan Informasi Publik

Vigoda, E. 2002. From Responsiveness to Collaboration: Governance, Citizens, and the Next Generation of Public Administration. Public Administration Review, 62(5), 527-540. doi:10.1111/1540-6210.00235 